International Journal of Applied Linguistics \& English Literature

ISSN 2200-3592 (Print), ISSN 2200-3452 (Online)

Vol. 1 No. 6; November 2012

\title{
Failed Quest in Samuel Beckett's How It Is
}

\author{
Alireza Najafi \\ Ph.D. Candidate, Faculty of Foreign Languages, Shiraz University \\ Eram Square, Faculty of Humanities, Shiraz University, Shiraz, IranShiraz University \\ E-mail: alirezanajafy@yahoo.com \\ Dr. Parvin Ghasemi (Corresponding Author) \\ Professor, Faculty of Foreign Languages, Shiraz University \\ Eram Square, Faculty of Humanities, Shiraz UniversityShiraz University \\ Tel.00989177160121_E-mail:pghasemi54@gmail.com,pghasemi@rose.shirazu.ac.ir
}

Dr. Farideh Pourgiv

Professor, Faculty of Foreign Languages, Shiraz University

Eram Square, Faculty of Humanities, Shiraz University, Shiraz University

E-mail: f.pourgiv@gmail.com

Received: 21-08- 2012

Accepted: 06-09- 2012

Published: 01-11- 2012

doi:10.7575/ijalel.v.1n.6p.247

URL: http://dx.doi.org/10.7575/ijalel.v.1n.6p.247

\begin{abstract}
In this paper Beckett's novel, How It Is, is discussed in the light of the monomyth of quest. It is argued that this novel does not follow the traditional framework of novel and it has an antihero of the twentieth century with a vague and uncertain quest. In most works of fiction, the quest is followed by fulfillment and accomplishment to make the protagonist worth his painstaking labor and suffering, while with Beckett's characters, failure becomes the dominant issue. Most of his characters are narrators of their own tale who face failure of expression though they are obliged to express it. The characters with one syllable names of Bem, Bom and Pim represent the mankind stuck in the "mud" of the present unable to distinguish past, present or future. There is a constant tendency to reach the goal which is unattainable.
\end{abstract}

Keywords: Beckett, Quest, Monomyth, How It Is, Failure, Joseph Campbell

\section{Introduction}

In mythology and literature, a quest is a journey towards a goal conducted by the hero or the major character. Quests appear in the folklore of every nation playing a prominent role in non-national cultures. In literature, the object of quest requires great exertion on the part of the hero, the overcoming of many obstacles, as well as travelling over a body of water. In the traditional tales of hero adventure, the hero is endowed with extraordinary powers from the moment of birth. "The standard path of the mythological adventure of the hero," according to Campbell's The Hero with a Thousand Faces (1949), is a "magnification of the formula represented in the rites of passage: separation - initiation — return: which might be named the nuclear unit of the monomyth" (p. 28). A hero starts upon a journey from his ordinary world and enters into a world of supernatural wonders; he encounters forces and wins victories. The hero returns from this mysterious adventure having gained insight and has the power to bestow blessing on his fellow men.

In Joseph Campbell's description of the hero cycle, the adventure is always a passage beyond the known into the unknown; the powers that watch at the boundary are dangerous; to tackle them is risky, but for any one with competence and bravery the danger will disappear. This is a descent into the dark in which the conscious personality has connected to a change of unconscious energy which is almost impossible to handle. Campbell in his other book, The Power of Myth (1988), states that the hero must suffer all the trials and tests of a terrifying sea journey, while he will learn how to come to terms with the power of the dark and emerge to a new way of 
life. He adds that there are two kinds of heroes: those who choose to undertake the journey and those that do not. In the former, the hero sets out responsibly and intentionally to perform and achieve the goal or quest, while in the latter, the hero is thrown into the adventure. He has not intended to accomplish anything but what he is ordained to.

The character of the modern novel cannot be labeled as hero performing certain heroic actions because the individual's sense of his own potency, as Ihab Hassan (1973) states "his power to effect change and mold events, seems in steady decline. It is no great wonder that men choose to withdraw from the public realm of action, though their withdrawal from the world compels them into a fragile or futile relation to themselves" (p. 15). Solipsism, the situation in which the individual self is unaware of anything beyond itself, separates a character so much from the external world that subjective reality stops being reality. When emphasis on the subjective qualities of character suggests that selfhood is always changing and unstable, another problem appears: identity disappears by the diversity that comprises the self. Selfhood gets split up so much that it misses being a constant character.

\section{Discussion}

The purpose of this study is to unravel the way Samuel Beckett deals with the concept of quest in his novel, How It Is (1964). Unlike the other works of art containing a significant quest imposed on the hero/character, Beckett's character is an antihero of the twentieth century with a vague and uncertain quest. In most works of fiction, the quest is almost always followed by fulfillment and accomplishment to make the protagonist worth his painstaking labor and suffering, but when it comes to Beckett's characters, failure becomes the dominant issue. Most of his characters are narrators of their own tale who face failure of expression though they are obliged to express it. A step forward in Beckett's world is a step backward. Nowhere do we see any ground which supports man's life or can stand as its touchstone to be compared with. As A. Scott Nathan (1962) has observed of the image of man in Beckett's world " man is nothing because there is nothing either in or beyond existence that sanctions or gives any kind of warrant or dignity to the human enterprise' (p. 178). In his world being is reduced to the most minimum possibility, existence is pointless, and man is a decrepit robot in search of a self which he can never find, and which, if he found, he could not know, and if he knew it, could not express or love it.

The underlying theme of all of Beckett's work as Laura Barge (1977) says is 'this search of the heroes for whatever constitutes metaphysical reality, for the ground of being which is the essence of truth at the core of human experience"' (p. 276). Obsessed with this search and considering its aim to be covered at the bottom of human consciousness, the protagonists turn from the macrocosm and dive deeper into the microcosm in search of what they desire. What the characters face coming down to the microcosm is just a void or nothingness. Because what is being searched for is something that is there, it is paradoxically not only negative but also positive, "a plenum-void" (Barge, 1977:277). It never gives any substance but continually goes back into infinity. The Cartesian character is entangled in the inner subjective world so much that he is reluctant to deal with the objective one, so his reaction towards the outer world establishes the form of defense mechanism facing others and he, finally, resumes for the unattainable real identity or selfhood. He attempts to protect himself against the dangers to his being which are the result of his failure to achieve a secure sense of his own identity. Beckett's whole cannon is the character's struggle to reach the reality which is receding as it seems to be attainable. Despite the failure, the attempt for accomplishing it is endless and ongoing.

Being projected into life, Beckett's hero suffers from the pain of all kinds in darkness without identity, but he is permanently in motion to achieve extinction as a goal. The void of annihilation can be the desired destination, which can be sought in love, lust, return to the womb, and mirage of death. By nothing or the void, Beckett does not mean the negative connotation of death. Instead, he means the absence of physical life, not negation, but affirmation; " affirmation of the reconciliation of the conflicts and dualities which life is to replete especially the duality of subject and object'" (Steinberg, 1972:93). However, the hypothetical imperative--which is manifested in another human being, object, or an unknown voice-- obliges him to leave the void and continue without any gain. The void sucks him into nothingness or annihilation, but the hypothetical imperative pricks him in the opposite direction. The void has arrayed its motives: dissolving body, time's corruption, the travesties of love, the hideous qualities, but at the final moment, there is a final hail. Just at the point of prenatal darkness, of an artificially evoked womb, he cannot remain and has to listen and follow the urgent call whether from inside or outside.

The final hero of the trilogy, The unnamable, defines the problem exactly 'there is no name for me, no pronoun for me, all the trouble comes from that' (p. 404). He offers the only feasible solution in Beckett's world "' I'll go on, you must say words, as long as there are any, until they find me, until they say me'” (p. 414). Hence, the existence

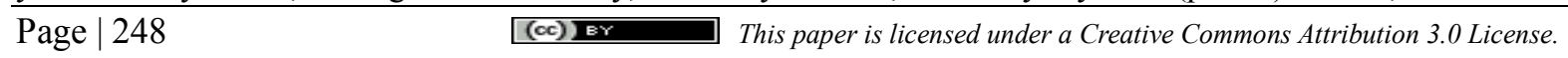


of the unattainable goal. Beckett denies the claim of literature " to contain the truth" (Wellershoff, 1965:92). His endless speech is the history of the human spirit to transcend thought and remain the prisoner of fictions he himself produces; he is a human being who does not know himself and who cannot tell who he is, where he is, and wherefore he is. He tries to talk about it and " thus merely enlarges his own darkness in which he is incapable of finding himself' '(ibid 93).

How It Is marks a significant turning point in Samuel Beckett's fiction. All Beckett's other works employ at least minimal punctuation and keep the sentence and paragraph as the basic units of composition, but this novel features completely unpunctuated prose in fragments that need other terms describing them. Knowlson and Pilling (1979) call them 'versets' (p. 63) and Gidal calls them "segments' (p. 47). These parts or paragraphs do not coincide with semantic units and do not rely on the syntactic cohesion. The discontinuous format of the text consists of unpunctuated segments separated only by the blank space of the page. It is the story of an unknown and unnamable narrator telling what is told to him by a voice he is not sure to be from within or from without. The narrator is an immobile prostrate figure who, while waiting for an end, fills the time to that end with a continual flow of words.

The work is divided into three parts, and within those parts--before Pim, with Pim, and after Pim--the narrative is cut into small fragments by breaks, suggesting a sequence of thoughts punctuated (not by comma, dot, colon, semicolon, etc.) by moments of silence. The moments of silence are the times he is panting unable to express his thoughts or the voice's. Thus, we have three different but related modes of being or life that are connected by an internal voice; there is the present moment of a man murmuring, the recording of his life, and the incomplete memories that encompass his former life recollected and spoken by a voice in his head.

The first part represents the wish on the part of the narrator to reach Pim by the end of the journey he has gone through. During this trip the narrator or Bom, as he calls himself, he tells of his world and of the fragmentary memories of a life above. The second part relates the moment of meeting Pim and how he makes Pim speak using different kinds of tools like the can opener and nails. The narrator in the second part plays the role of tormentor torturing Pim. In a grotesque play of sexual coupling and education, this torturing happens. In the last part, Pim abandons the narrator to reach a victim to perform the kind of abuse that he was subjected to by the narrator upon him. The narrator, being deserted by Pim, has to wait for a tormentor to be victimized and this process will continue infinitely. Here, Bom proposes an endless cycle of torturers and victims while preparing himself for his own encounter with his tormentor. Finally, he admits that the only voice he hears is his own, that Pim and other creatures are all illusions and the only real thing is progression inside mud.

The central event, then, seems to be an interaction between the speaker, claiming to be mute, and another creature, Pim, who speaks but is mentioned not to exist. It is the character of Pim which provides the narrator with the means of organizing the novel through its tripartite structure of a beginning, middle, and an end. Inasmuch as he remains a purely fictional entity distinct from the narrative subject, the invention of the character of Pim can be seen, then, as David Watson (1991) states "the evocation of another, an objective reference point around which a narrative can take place" (p. 93). Watson adds that without Pim no narrative can be found. Therefore, without narrative the narrator can find no site for the representation of the subject. On the one hand, Pim is the fictional creation of the narrator. On the other hand, the narrator's subject position depends on the prior existence of Pim's narrative. As a result, both the narrator and Pim need each other's existence, without the existence of one, the other is doomed to nonexistence. The narrator is referred to as a quadim, somebody or one unknown, "in the light first image any quadim I looked at in my way from afar furtively in a mirror" (p. 11).

Like most of Beckett's characters, Bom is old as well as being disabled signifying the Cartesian concept of the impotence of the body in contrast to the mind. The journey is the reenactment of Dante's journey into hell. The characters in Beckett reminds one of Dante's characters striving to leave the horrible hell for the land of bliss in paradise in Divine Comedy (1955). Ross Chambers (1965) believes Beckett's characters are not on the uncrossable brink of entry into some kind of heaven, so that for them existence is a purgatory on earth. They are in a kind of no man's land, lying somewhere between their existence in time and their life in eternity, neither the one nor the other. Typically their lives are over but have not ended, which resembles Dante's Belacqua who has been condemned to live his life over again in expectation of admission first to purgatory and thence eventually to paradise. The narrator mimics the words at the gate of Dante's inferno "mute screams abandon hope gleam of hope ... abandoned here effect of hope" (p. 46).

How It Is starts with the narrator's invocation, an epic convention which is an appeal or a request for inspiration, addressed to a Muse or deity. The epic writer asks the help of a Muse to inspire his composition of the heroic poem he has begun. The same way in How It Is invocation is found: "Voice once without quaqua on all sides

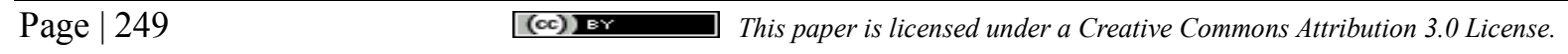


then in me when the panting stops tell me again finish telling me" (p. 7). This invocation is not addressed to a Muse or deity but to the voice which is within or without. He asks the voice to tell him everything about his whereabouts and life, something which he is unsure about while he is stuck in the mud and darkness. He is doubtful whether the voice is inside him or outside.

The voice can also be considered as the ancient voice which is talking to all humanity: "in me that were without when the panting stops scraps of an ancient voice in me not mine" (p. 7). The voice he is alluding to is ancient and universal. It has been with man from the beginning of creation but certainly it is not his voice as he admits it. The fact is that he does not know where the source of the voice is although he is spoken to.

The narrator or quadim lives in a primeval world of mud and darkness listening to the voice of his thought and pleading to that voice, as if extended to his consciousness, to allow him to participate in the creative process of how life was, is, and will be before Pim, with Pim, and after Pim. The novel mocks itself as a narrative of citation because the opening invocation invokes no one, the dispossessed writer hearing, quoting, and recording nothing, except something which is involuntarily imagined. However, the voice must be an unknown external one which should be beseeched in order to get the inspiration required for the composition of the adventure.

These paradoxes may finally be attributed to the narrator's reference at the outset of the novel to a voice allegedly responsible for the narration to follow and which the narrator claims to cite. In fact, the narrator's recourse to "narration in terms of citation at the outset of the novel is equivalent to the latter's ascribing the cause of his speech to a higher cause in relation to which he is the obedient effect" (Singer, 1983:126).

The central issue is what kind of a quest it is. Many questions come to the mind. What is that goal that has obsessed the narrator or Bom's mind? Is the aim something tangible or not? Why is the quest so defining for Bom? Is the goal worth every effort the character has gone through? Is the quest for reaching Pim in the dark with the load of tins in his sack tied to his neck through mud whether crawling or ambling, indicating the difficulty of movement in such difficult conditions? He is not feeling safe anywhere; that is why he is on transition from one place to another looking for some security and relaxation. Nonetheless, it is just home that can give him that feeling of safety and satisfaction. On his way, he is searching so many roads and shortcuts that can lead him to the desired place. Answering the question of how this novel is perceived as a quest is not a difficult task when realizing that the journey referred to in the novel, especially the first part, brings to mind the description of the heroic adventure being introduced by Joseph Campbell. Moreover, the novel is in the form of an epic though no heroes and perilous struggles can be recognized as you read it.

According to Campbell, the hero goes through the three stages of separation, initiation, and return. When it comes to this novel, we find the narrator or antihero in the middle of darkness and mud. The images he remembers or makes Pim remember are about the life above where light existed in contrast to the darkness of the underworld or where he has been located. From the very beginning we are in the phase of initiation in the darkness without any separation; that is, the separation has already started before the novel starts. It seems the narrator has been separated from the place of light above but the reason of this separation is vague or uncertain.

The modern man in Beckett's world suffers from lack of identity, isolation, loneliness, and alienation. His situation in the $20^{\text {th }}$ century is like a man caught in the darkness and mud. He is struggling to move forward and get rid of the chains of the wasted world symbolized by mud which is undifferentiated from every view looked at. It is a quest that is essentially a descent into microcosm in which the art of fiction is involved through which the self is expected to be discovered, but the goal is evading.

The self lies outside time and space. It is on the other side of words, expression, and forms. However, it is the obligation of the artist to express himself which is the object of the quest. The journey becomes crippling and sounds to distance the seeker instead of bringing him closer to it. In other words, the journey strips the protagonist of the means of completing it. The quest never brings the quester nearer to his goals, but instead keeps him from it, at some indefinable distance.

The quest for self includes seeking identity, being, metaphysical reality, and meaning in life. In other words, after discovering the self the character will have identity and a sense of being. He will locate the true reality and his existence will be meaningful. The abstract concept of self has been symbolized in another creature called Pim. Pim has given organization and order to the whole story because the triadic structure of the novel is centered on Pim. Pim is described as the object of desire for the subject the narrator, who seems to be unobtainable though he is approached.

Being with Pim leads to the disappearance of loneliness. Finding his real self in the form of a companion can bring an end to his solitary life in the dark and mud. He is hopeful that soon his problem is solved and the lost 
goal will be found when Pim is met. The direction of the quest is from west to east indicating the fact that east, where the sun rises every morning in the sky, can be symbolized as the place of origin and light. Therefore, the progress toward the east reminds one of the fact that reaching the east he has achieved light and the source of his life. One can go towards the east but one can never reach it exactly, therefore they are always on the move towards it due to the circular shape of the earth. Hence, approaching the goal is possible though it is never achieved.

Bom tries to seek: "that which I have lost there where I have never been" (p. 52). He starts the journey by going somewhere he has never been before to search for something he has lost. The lost item can stand for his being, identity, or reality, which refers to self, in the shape of a companion which shouldn't delete in subject form called Pim. He thinks of possessing Pim the way he possesses his sack, "... he can't repel me it's like my sack when I had it still this providential flesh I'll never let it go call that constancy if you wish" (p. 61). He does not intend to lose Pim so he desires their relationship to be constant without any separation though it is impossible. Being with Pim would bring a drastic change in him because "... that with someone to keep me company I would have been a different man more universal" (p. 74). The companion would transform him into a different man than what he used to be when alone. He would be a more universal human being approaching the ideal model of humanity which is always wished as the final goal. Reaching Pim is not enough. Rather, it also includes imprisoning him in order not to lose him. He may escape and leave Bom alone to suffer his own hell.

The universality of the story of quest is being demonstrated when Bom mentions: "at that instant I leave Bem another leaves Pim and let us be at that instant one hundred thousand strong then fifty thousand departures fifty thousand abandoned no sun no earth nothing turning the same instant always everywhere"(p. 121). It is realized that he is one among a large number of couples that are acting the same way he has been doing so far. The words "always" and "everywhere" emphasize the omnipresence of the quest for all human beings.

Finally, the nonverbal quest is transformed to verbal when Bom mentions: "an image of this voice ten words fifteen words long silence ten words fifteen words long silence long solitude once without quaqua on all sides vast stretch of time" (p. 138). The same process happens in the narrator's voice in which speaking is followed by long silence and then it is started again. Before this, there was the movement forward by ten or fifteen yards, but now the movement happens on the part of words with ten or fifteen words.

Quoting Carl Jung, Enoch Brater (1974) states that the ego is that conscious part of the psyche focused on a center called the "I", but the unconscious part of the personal psyche is focused and personified as a sort of alter ego, the shadow. We are dimly aware of this alter ego which is abiding inside us. It acts in us as if it were another being, another self, with whom we can carry a conversation, taking part in a conflict when we are of two minds about a problem. The alter ego is really a part of the personality. As long as it remains unconscious, the human being can never be whole and suffers as a consequence of the pain of disintegration. It is important for the individual to become united with his shadow, giving it a place in the totality of his "I". As a result, we take the first step in the individuation process and in the development of a true self-consciousness.

Laura Barge believes that in this novel the situation is not related to the tension between macrocosm and microcosm. Rather, the landscape or interior is the microcosm, which is believed to be mindscape. This microcosm is inhabited by inner self and is now split into a condition of either being or becoming. There is a duality of the self-as-subject and the self-as-object. Thus, the inner self, isolated form its own body and voice as well as being withdrawn from macrocosm, becomes the object of its own perception in the confines of the mind. The search for the self as object is going on by the self as subject to obtain the desired purpose of bringing the unity of both.

As far as Bom, the narrator, can peer there is mud and darkness around him. Groping in an endless direction across it, moving "ten yards fifteen yards" he has no way of distinguishing where he is (present), from where he has been (past), or where he is to go (future). Since the mud is borderless and is not covered by anything, it denotes no place. If Bom has no place, he has no position in time. Time here is quite indefinite. John Fletcher states: "there exists no means of measuring it since there is no night and day, but he is at least certain that it is very long" (p. 214). Because Bom can know neither where he is nor where he has been, he cannot make any progress; the repetition of his movements, like those of his speech, bring him nowhere. As a result, he is in search of Pim to tell him about everything he needs to know concerning time, place, and himself.

Beckett's speaker cannot qualify as a member of a species when he is in mud and darkness. And if he cannot identify as part of a group, he will suffer the unknowability of the identity. Thus, he sticks to his species in order 
to keep a sense of identity and being because he knows he cannot be a universal man without having someone's company. This can account for his clinging to Pim as part of his species to remove him from nothingness.

Pim confers all the meaning that the life before humans can aspire to. In the absence of his name, Hugh Kenner (1973) says "acrid memories circulate without point, small mean words buzz, and we are reduced to such calming expedients as the drawing of free hand over the face" (p. 6). Having found his equal, his brother, whom he can martyrize, treat like an object and abuse at his will, Bom is no longer alone. He hears him, understands him, and shares his provisions and life. Thanks to Pim, he feels that he exists. The search for self is evident in the shape of Pim when Bom says: "... lie there in my arms the ancient without end me we're talking of me without end that buries all mankind to the last cunt" (p. 68). "Me" here can be deemed as self because he refers to himself as "I" but he is after "me". It is called ancient and it covers all human beings without end. The endlessness of this ancient self makes his quest a quest of humanity, "that he was necessarily that ancient other when it said I had suffered then forsaken to go towards Pim as Pim me suffered then forsaken to go towards his other" (p. 123). He means the collected unconscious that is universal and common to all human beings that are in quest of coming back to their original and real self, which is manifested here as the ancient other. Pim is "me" while he calls himself "I".

Bem's cleaving to him is like reuniting with his lost self. Being with Bem, he can obtain his lost identity because Bem like Pim can give him his name and his life which he used to have above in the light but now there is no name in darkness: "Bem come to cleave to me where I lay abandoned to give me a name his name to give me a life make me talk of a life said to have been mine above in the light before I fell" (p. 118). All of the characters in this novel are one even if they are millions because they are called Pim, or every name that ends with "m" and is made of one syllable. As he says: "... for more commodity that would appeal to me at the end and one syllable the rest indifferent" (p. 67). "M" is important because it connotes man in general. The Pims are stuck as a couple motionless reminding one of the collective unconscious where the memory of all of human beings are linked to the big memory collecting all the things human beings share. The self is unknown to everyone. Here one is a stranger not only to others but also to oneself. It is a place of ignorance and unknown. One is a stranger to oneself but one tries to realize it though in vain.

However, the fact is: "what we were then like a single body in the dark the mud" (p. 132). The couple, Pim and I, has been compared to a single body when they are stuck together. It indicates the fact that they are like body and soul or self and the other mixed at this instant. Self is compared to a home or isle to be conquered: "... I am looking for an isle home at last drop never move again a little turn at evening to the sea-shore seawards then back sleep wake in the silence ... live old dream on crabs kelp" (p. 94). Isle and home are the self he has in mind because finding it he does not need to move again. He will stay there enjoying the relaxation and sleep, it brings to his whole body. When in this position he will inhabit the third phase of Murphy's dream where he can be silent and stop talking forever.

David H. Helsa quotes Hegel in his book, The Shade of Chaos: an Interpretation of the Art of Samuel Beckett (1973), in the light of self and other. In order to know itself, the self must become an object to itself, but it can do so only by encountering another self-consciousness. Consequently, the self can understand itself only by recognizing it in the other. In doing so, the self loses itself in the other, because it discovers itself only as the other. So to recover itself, it must sublate its being-other in order to return to its being-for-itself. Consciousness must recognize the other as another being-in-itself and simultaneously, self-consciousness is being-for-itself in that it excludes every other from itself, so that the other is marked with the character of the negative. As a result, in view of the one, the other is the negative, though at the same time in the view of the other, the one is the negative. In the encounter between the one and the other, each tries to control his opponent. Either the one or the other will prove to be stronger, and he will emerge as independent for itself, whereas the weaker will become the dependent on another. It turns out that the former becomes the master and the latter the slave.

The discovery of Hegel is that the other is not located only out there in the world, but is also in here as an integral and essential element of the self. The unhappy unconscious is the doubling of itself into itself and the other, and the other is the principle of contradiction and negation interior to the self. The struggle between the master and the slave is the struggle within consciousness of all the contradictions such as active and passive, motion and rest, and determinacy and indeterminacy. If consciousness desires to rest in one of these paired terms as the one, it faces its opposite and other.

It is the issue of self and the other that can account for the failure on the part of quest for the seeker's identity and being. If self needs to find the other, in return to its real position it has to negate it and this struggle goes nonstop. The self as the subject cannot be identical to the self as object and their merging will result in no union.

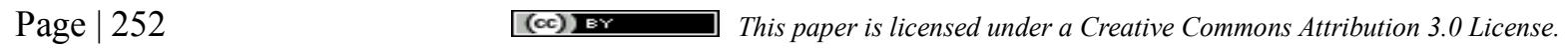


Therefore, he has to withdraw the quest he has started, but later he will start it again. For the hero/character of Beckett, there is no bridge between the self as the subject and the self as the object. For this reason, he can achieve no unified concept of self and no identity. He is left with an inner voice which, like his movements, is broken and fragmentary in speech signifying not only the nonverbal but also the verbal disintegration.

The dimensionless self exists outside the world of space and time and is not achieved in that world. It is the same as the center of a circle in that it exists but we cannot attain it. Each attempt to circumscribe it just creates, not a center, but a new circumference which itself has a new center. Therefore, to approach the self is to struggle on a limitless process. Life as the chasing of self becomes the endless and disappointed task of following an infinitely receding object.

Murphy's mind consists of three zones: light, half-light, and the dark. In the first zone, the mind is able to readjust the elements of physical experience, memory, imagination, as well as the will. In the second zone are ", forms without parallel" (p. 111) in the physical world; the pleasure consist in contemplation and minimum of effort is required. The last zone is the dark containing a "flux of forms, a perpetual coming together and falling asunder of forms" (p. 112). The dark is that area of experience containing purity of will. The self in this zone is described as " a mote in the dark of absolute freedom" (p. 112). It is a void without form, a chaos. Thus, the movement in mind is a movement from light to dark, from forms with physical parallels to the void of nothingness. It is the third zone that Beckett's characters strive for but they are always regretful for not reaching it as a result of the call of return. Ethel F. Cornwell believes that the heroes long for a release from spatial and temporal consciousness as they experience it and that they are obsessed with any state that seems to offer relief.

The three divisions of the book show three stages in the development of the narrator's consciousness. Part one represents the earliest stage, before self-consciousness happens. With the development of self-consciousness in part two comes the division between the self as subject and the self as object. Pim symbolizes the narrator's selfas-object when he says "my life up there" (p.76). 'Up there' refers to the external world and it is paralleled to Murphy's zone one as the zone of light. Down here, in contrast, refers to the inner recesses of the mind to which the narrator has entered as consciousness. It is the second phase in Murphy's circle with light and dark mixed. However, retreating to the third zone of complete darkness, unity of the subject and object, is impossible as this is the problem with all of Beckett's characters.

This failure of the quest signifies imprisonment in the I-consciousness. It is the inability to unify with what is outside the consciousness. According to John Pilling (qtd. in Davies 1994), "hell is not so much other people as oneself: the truly infernal experience is to be immured in one's own consciousness with one's own illusory companions" (p. 120). The bone white structure is able to receive light and distribute but is imprisoned in darkness. I-consciousness is located in the skull, thus bone white structure needs light to know itself but he just can get very quick images of the light in the form of memory. The light is needed to transform the consciousness but the desire for light is covered in the middle of mud and darkness.

Only he who has attained to his own identity can be silent, only when thinking has reached reality, it can come to a stop; otherwise, it will go on contemplating and the voice will speak over and over again. The more urgent the demand for truth, the clearer it appears incapable of fulfillment. Thus, Beckett gives us the illusion of arrival but at the same time he destroys the other illusion that the useless quest can ever be finished. The character's awareness of his own self continues interminably; and time can never have a stop. As the individual can never become cognizant of his own ending, his final moments of consciousness must remain eternally suspended in limbo, symbolized as darkness and mud, and can be conceived as reappearing through all eternity. The protagonist or the narrator is suspended in the sphere of his own consciousness, between the false heaven of the macrocosm and the interminable hell of microcosm. This sphere ' 'becomes", as Laura Barges (1977) stated, ' a place of crucifixion where man as victim endures the suffering of self-perception'" (p. 275), which is the most frightening of all human observations.

A close look at the novel itself reveals this fact that failure of the quest is predominant in all three parts. In the first part, he mentions: "my life last state last version ill-said ill-heard ill-recaptured ill-murmured in the mud brief movements of the lower face losses everywhere" (p. 7). The signs of loss can be seen here where everything is impaired and flawing. Loss is present everywhere. He also uses the word "'last'" to indicate his own condition which is nearly ending. The words that start with the prefix "'ill-" signify his impotency because saying, hearing, capturing, and murmuring - those things related to senses and memory - are at fault. Moreover, these compound words starting with "ill', remind the reader of Beckett's another novella, Ill Seen Ill Said (1981). 
In the last part, everything is gloomy when he mentions: "all that almost blank nothing to get out of it almost nothing to put in that's the saddest that would be the saddest imagination on the decline having attained the bottom what one calls sinking..." (p.112). This refers to when he is abandoned by Pim. We have the last part of his life where everything is upsetting with no input or output. The failure can be confirmed when it is revealed in all parts of the novel in the shape of ignorance and lack of identity, loneliness, emptiness and lack of fertility, and finally darkness. Silence and solitude have engulfed him to the extent that he says: "... the silence the solitude nothing else for the moment" (p.9).

The tormenter-tormented story he imagines is a desperate effort by a consciousness, to unlock with a can opener the inner being of some other who is the elusive self, and thus to initiate the motionless crucifixion of further search into the soul. The tormentor victim process brings to mind the subject-object relationship in which the subject has the upper hand of forcing, victimizing, and manipulating the object.

The way Bom torments Pim is stated in different manners like digging nails into his armpit, thumping with fist on his skull, clawing his left hand to the bone, imprisoning him, and stabbing him in the back side. All these actions show tormentor's inhuman treatment of the victim, as if Bom is treating Pim like an animal. Eric P. Levy (1980) claims "if the relationship between Bom and Pim fails to rescue their humanity, it also denies each his individuality" (p. 87). The creatures are tormentor and victim by turn; that is, Bem is tormentor to Bom, but when Bom abandons Bem he moves towards Pim to play the role of tormentor. Being tormented by Bom, Pim leaves him to travel towards his victim and this process continues endlessly. Generally speaking, once you are a victim, then you are a tormentor in the next part of your adventure. As the narrator says: "it is stopped at the season of our couples and in that case one half of us tormentors in perpetuity victims in perpetuity the other" (p. 154).

In a man can be found a combination of being victim and tormentor; thus, man can have both inclinations. As tormentors, it is our urge to remain but as victims it is our desire to move on. When being remained causes failure, the urge to move on overweighs the former leading to continue what we have failed to reach. The idea of continuing in spite of failure can be deciphered throughout the novel as when he says:

you are there somewhere alive somewhere vast stretch of time then it's over you are there no more alive no more then again you are there again alive again it wasn't over an error you begin again all over more or less in the same place or another... ( p. 24).

We have failure and the obligation to continue here. At first you are alive somewhere but then everything is finished. However, you begin again because it was not finished. This process goes on and on in Beckett's work endlessly.

What The Unnamable mentioned in the last line is repeated here when Bom says: "... part three and last one can't go on one goes on as before can one ever stop put a stop that's more like it one can't go on one can't stop put a stop" (p. 99). The quest ends here with no desirable result, but he cannot help going on. It is not possible to go on; however, you have to resume. Or one cannot go on, but one should not stop, therefore, movement towards the goal is recommended. Beckett makes each verset sound both an end in itself and part of a greater whole. The French title, which is a pun on commencer--to begin-- could be apt here because the book is always beginning again and ending again a few words later and hence the narrator's life seems very much like something over which still goes on.

\section{Conclusion}

Finally, the narrator gives a big shock to the reader by stating what the Unnamable mentioned of himself: "I'm a big talking ball, talking about things that do not exist, or that exists perhaps, impossible to know, beside the point" (p. 305). Bom astonishes the reader when all the attempts to reach a state of knowledge are declared to be balls. The narrator admits that the business of voices, of sacks, of light and dark, as well as the creatures he met are all fabrication, even the journey itself. It illustrates the failure the narrator experiences when he views "his array of bits and scraps and compares them with what he might have created had he been given, or seen, the light" (Davies, 1994:125). The words suggest that everything in the book that are concerned with imaginative reality are as much balls as the end of the book claims all that precedes it. Linda Ben-Zvi has the same idea when she states: "the impossibility does not keep the speaker from continuing to talk, however, for talking is the only form of thinking possible" (p. 188). Since the ego has no way of articulating itself, it cannot be verbalized and thus can never be known. That is why the narrator can never be silenced and has to continue talking. We have a narrator panting out words "in a doomed, but unremitting attempt to elude their silence and arrive at the promised land of their own silence..." (Fletcher,1967:22), the true silence that they never find. 
The "warmth of primeval mud impenetrable dark" (p. 12) stands for the void in which he enjoys dwelling but there is the voice or hypothetical imperative which forces him to continue the search for something, self, that does not exist, and if it exists it is unknown, or if it is known it cannot be expressed by this faulty language. The episode before Pim is referred to as the golden age in which good moments are realized. In those good moments, the loss of contact with human species is celebrated where you are in contact with your real self. Dark is warm and pleasant because it brings him back to the primeval and original mud of life. But the voice or the hypothetical imperative has a universal function because he is not the only one hearing it. The voice incites some motion on the part of the hearer to leave the void and continue though failure has the upper hand. The voice transcribes its thoughts as faithfully as possible. It only stopped speaking when it needed to pant for breath. The problem of identity has caused a change in the title of the novel, different from the previous ones with the name of the major characters. The title indicates that "It" is now the narrator who has superseded all the others because it has gone beyond the bounds of gender.

\section{References}

Alighieri, Dante. (1955). The Divine Comedy. (2 ${ }^{\text {nd }}$ edition). Tran. \& ed. Thomas G. Bergin. New York: Appleton, (Purgatory).

Barge, Laura.(1977). Colored Images' in the 'Black Dark': Samuel Beckett's Later Fiction. PMLA, 92, $237-84$.

. (1977). Life and Death in Beckett's Four Stories. South Atlantic Quarterly, 76, 332-47.

Beckett, Samuel. (1964). How It Is. (3 ${ }^{\text {rd }}$ edition). New York: Groves Press.

..(1979). Murphy. ( $3^{\text {rd }}$ edition). New York: Grove Press.

(1958). The Unnamable. ( $3^{\text {rd }}$ edition). New York: Grover Press.

Ben-Zvi, Linda. (1980). Samuel Beckett, Fritz Mauthner, and the Limits of Language. PMLA, 95, 183-199.

Brater, Enoch. (1974). The I in Beckett's Not I. Twenty Century Literature, 20, 3189-200.

Campbell, Joseph. (1949). The Hero with a Thousand Faces. (1st edition). Princeton: Princeton UP, (chapter 7).

.............. (1988). The Power of Myth. (2 ${ }^{\text {nd }}$ edition). New York: Doubleday, (chapter ten).

Chambers, Ross. (1965). "Beckett's Brinkmanship" in Samuel Beckett: A Collection of Critical Essays. $\left(3^{\text {rd }}\right.$

edition). Ed. Martin Esslin, New Jersey: Englewood Cliffs, (chapter five).

Cornwell, Ethel F. (1973). Samuel Beckett: The Flight from Self. PMLA, 88, 41-51.

Davies, Paul. (1994). The Ideal Reader: Beckett's Fiction and Imagination. (1st edition). London: Associated UP, (chapter 3).

Fletcher, John. (1967). Samuel Beckett's Art. (1st edition). London: Chatto and Windus, (chapter 1).

Gidal, Peter. (1986). Understanding Beckett: A Study of Monologue and Gesture in the Works of Samuel

Beckett. ( $5^{\text {th }}$ edition). London: Macmillan, (chapter 8).

Hassan, Ihab. (1973). Radical Innocence: Studies in the Contemporary American Novel. (5th edition).

Princeton: Princeton UP, (chapter 2).

Helsa, David. (1871). The Shape of Chaos: an Interpretation of the Art of Samuel Beckett. (3 ${ }^{\text {rd }}$ edition).

Minneopolis: University of Minnesota Press, (chapter 5).

Kenner, Hugh. (1973). A Reader's Guide to Samuel Beckett. (2 ${ }^{\text {nd }}$ edition). London: Thames \& Hudson, (chapter 5).

Knowlson, James and Pilling John. (1979).' 'How It Is'” in Frescoes of the Skull: The Later Prose And

Drama of Samuel Beckett. (1st edition). London: John Calder,(chapter 2).

Levy, Eric P. (1980). "How It Is: An allegory of Time and Personal Identity." in Beckett and the Voices of

Species: A Study of the Prose Fiction. (1st edition). Dublin:. (chapter 10).

Nathan, A. Scott. (1962). The Recent Journey into the Zone of Zero: The Example of Beckett and His Despair of Literature. The Centennial Review, 6, 167-178.

Singer, Alen. (1983)."The Need of the Present: How It Is with the Subject in Beckett's Novel." In A Metaphorics of fiction. ( $3^{\text {rd }}$ edition). Gainesvillee: UP of Florida, (chapter 4).

Steinberg, S. C. (1972). The External and Internal in Murphy. Twentieth Century Literature, 18, 92-109.

Waston, David. (1991). Paradox and Desire in Samuel Beckett's Fiction. (3 ${ }^{\text {rd }}$ edition). London: Macmillan, (chapter 3).

Wellershoff, Dietor. (1965). 'Failure of an Attempt at De-Mythologization: Samuel Beckett's Novels"' in Samuel Beckett: a collection of Critical Essays. Ed. Martin Esslin. (2 ${ }^{\text {rd }}$ edition).New Jersey: Englewood Cliffs, (chapter 9). 